This is the author-created draft version of:

Growth and spread of native perennial herbaceous species on a green roof Authors: M. D’Arco, L. Ferroni, A. Velli, M. Speranza

ISHS Acta Horticulturae 1215 pp. 237-246

The original publication is available at DOI: $10.17660 /$ ActaHortic.2018.1215.43 


\title{
Growth and spread of native perennial herbaceous species on a green roof
}

\author{
M. D’Arco1,a, L. Ferroni1 ${ }^{1}$ A. Velli² and M. Speranza1 \\ ${ }^{1}$ Dipartimento di Scienze Agrarie (DipSA), Alma Mater Studiorum Università degli Studi di Bologna, Italy; ${ }^{2}$ Via \\ Tambroni 12, Bologna, Italy.
}

\begin{abstract}
The European Communication on Green Infrastructures encourages the use of wildflower verges, green walls, green roofs, etc. to mitigate the artificiality of the urban and rural environment. Green roofs are engineered ecosystems occupying underutilized urban spaces that rely on the plant cover to provide services, such as the reduction of temperature, retention of storm-water and enhancement of urban biodiversity. In this framework we explored the ability of some wild perennial species of arid and semi-arid grasslands to survive and colonize the substrate of the extensive green roofs of the Agricultural Sciences School of the University of Bologna. In midJune 2015 young plants of Festuca ovina L., Thymus serpyllum L., Hieracium pilosella L., Acinos alpinus (L.) Moench, Sanguisorba minor Scop. and Achillea millefolium L., coming from wild local populations, were transplanted into containers $(54 \times 54 \times 9 \mathrm{~cm}$ depth) forming the upper cover of a green roof. The plants were fertilized and then irrigated throughout the summer of 2015. The growth of the species (coverage and space occupation) was monitored approximately once a month, from August 2015 to May 2016. F ovina reached the highest values of coverage, without any significant seasonal variations. T. serpyllum and $H$. pilosella reached moderate coverage values depending however on the seasons. A. millefolium showed very effective dispersal abilities, but poor coverage potential. It can be used as a filler species in multi-species green roofs. Our results showed that the wild local flora can be an important, though still poorly explored, reserve of biodiversity for a new generation of extensive green roofs, designed, following a careful selection of species, for the best possible performances of the services they provide.
\end{abstract}

Keywords: green infrastructures (GI), extensive green roofs (EGR), wild species, urban biodiversity, ecosystem services

\section{INTRODUCTION}

The European Communication on Green Infrastructures and the European Strategy on Green Infrastructures (COM, 2013), as well as the associated planned network of natural and semi-natural areas, aim to improve environmental conditions, citizens' health, and quality of life in the European territory. They also support green economy, create job opportunities and enhance biodiversity.

Since green spaces in cities are becoming progressively reduced, roofs, which can reach up to $32 \%$ of the horizontal surface of the built-up areas (Frazer, 2005), have been identified as important underused places where plant cover can be developed (Franzaring et al., 2016). In Germany, in the early $21^{\text {st }}$ century, the diffusion of green roofs increased by

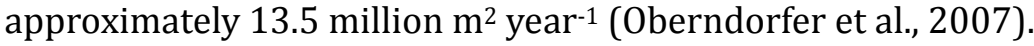

The potential environmental benefits of green roofs are numerous (Del Barrio, 1998; Köhler, 2003; Porsche and Köhler, 2003; Dunnett and Kingsbury, 2004; Oberndorfer et al., 2007; Aronson et al., 2014; Franzaring et al., 2016). However, till now green roofs have been constructed with attention paid mainly to the architectural and engineering problems and much less to the quality, performances and environmental congruence of the plant cover, as well as to the possibilities offered by the utilization of the wild species of the local flora.

${ }^{a}$ E-mail: matteo.darco2@unibo.it 
These environmental joint values have only recently begun to be considered (Cook-Patton and Bauerle, 2012) in the realization of green roofs, experimenting with plant covers alternative to those most frequently adopted, commonly involving a mixture of Sedum species (Monterusso et al., 2005; MacIvor and Lundholm, 2011; Blanusa et al., 2013; Aronson et al., 2014; Vestrella et al., 2015).

Results are sometimes contradictory (White and Snodgrass, 2003; Monterusso et al., 2005) and further experiments are necessary to tune the utilization of native species for green roof cover, maintaining the environmental services they usually supply (Brenneisen, 2006; Lundholm, 2006; MacIvor and Lundholm, 2011).

The current study aims to test the survival, growth and ways of space occupation of six wild herbaceous perennial species, from arid and semi-arid temperate grassland communities (Xerobromion and Mesobromion communities) planted on an extensive green roof in the city of Bologna, with a commercial stratification. Given the habitat where these species naturally occur, they appear potentially interesting for the plant cover of green roofs subjected to a climate of sub-Mediterranean type, with hot and moderately arid summers, humid and moderately cold winters, and managed with minimum irrigation and fertilization.

\section{MATERIALS AND METHODS}

\section{The green roof design}

The green roof where the experiment was performed has a surface of $12 \times 5 \mathrm{~m}$ and covers a low building of the Agricultural Sciences School of the Bologna University (Bologna, Italy). The stratification adopted has a total depth of about $18 \mathrm{~cm}$, where the upper part is organized in quadrat modules of $54 \times 54 \times 9 \mathrm{~cm}$ depth, made of regenerated plastic, interlocking each other and filled with pumice grains $(\varnothing 3-6 \mathrm{~mm})$ and with VULCAFLOR ${ }^{\circledR}$ up to the brim. The surface of each module is covered with $2 \mathrm{~cm}$ depth of white pebble gravel as mulching. The bottom part of the stratification, lying under the modular system at a depth of about $9 \mathrm{~cm}$, consists of a system of bags which the roots of plants can penetrate, filled with perlite grains and functioning as a water reserve. The green roof area used in this study comprises 60 modules arranged in 10 rows, each with 6 modules.

\section{The plant species}

We selected six herbaceous perennial species coming from wild local populations of arid and semi-arid grassland communities (Xerobromion and Mesobromion communities). The wild plant material was propagated and maintained under cultivation in a nursery for almost one year before planting on the green roof. In particular the tested species were: Sanguisorba minor Scop. (Rosaceae), Thymus serpyllum L. and Acinos alpinus (L.) Moench (Lamiaceae), Achillea millefolium L. and Hieracium pilosella L. (Asteraceae), Festuca ovina L. (Gramineae). All are frequent on well-drained soils and are drought-tolerant, but have different ways of growth, expansion and available space occupation.

As far as the latter aspect is concerned, the studied species can be distinguished into two main groups (Table 1). The species of the first group colonize the available space by forming a continuous and compact cover. This group includes $S$. minor, a perennial medium size forb with a basal rosette of compound leaves, which expands uniformly during springsummer (Sydes and Grime, 1984), A. alpinus which creates very small bushes, and F. ovina, a perennial caespitose small tussock-forming grass, that grows in tufts. The second group comprehends stoloniferous creeping species that quickly spread horizontally through stolons (T. serpyllum and $H$. pilosella), or more slowly through rhizomes, such as $A$. millefolium, where an efficient sexual reproduction coexists with the vegetative propagation (Warwick and Black, 1982). The species of the second group colonize the available space by forming a discontinuous cover, with many empty patches. 
Table 1. Habitus of the studied species, parameters and number of samples monitored.

\begin{tabular}{lccc}
\hline Species & Habitus & Parameters observed & Nr. of samples \\
\hline S. minor & Basal rosette & Rosette area $\left(\mathrm{cm}^{2}\right)$ & 3 rosettes/module $\times 6$ modules \\
A. alpinus & Bushy & Branch length $(\mathrm{cm})$ & 6 branches/module $\times 12$ modules \\
F. ovina & Caespitose & Number of shoots & 3 tufts $/$ module $\times 18$ modules \\
T. serpyllum & Creeping & Stolon length $(\mathrm{cm})$ & 6 stolons/module $\times 12$ modules \\
H. pilosella & Stoloniferous & Stolon length $(\mathrm{cm})$ & 6 stolons/module $\times 6$ modules \\
A. millefolium & Rhizomatous & N. of new shoots per rhizome & 5 rhizomes/module $\times 6$ modules \\
\hline
\end{tabular}

\section{Planting and growth monitoring}

In mid-June 2015, each of the 60 modules of the green roof was planted with a given number of individuals, depending on the species considered. In detail, we planted 5 plants of $S$. minor/module, in 6 modules, 5 plants of $A$. alpinus/module in 12 modules, 32 shoots of $F$. ovina/module in 18 modules, 5 plants $(1 \mathrm{~cm}$ rhizome) of $A$. millefolium/module in 6 modules; 4 plants of $T$. serpyllum/module in 12 modules and 4 plants of $H$. pilosella/module in 6 modules. At the start of the experiment each species covered a very low percentage of the available space of each module (from $0.5 \%$ to $\leq 5 \%$ ).

The monitoring period started in August 2015 and finished in May 2016. From August 2015 to October 2015 and from February 2016 to May 2016, we monitored the plants' growth once a month. In order to better describe the behaviour of each species in colonizing the available space of the modules, different morphological parameters were monitored (Table 1), depending on the species and its particular way of growth.

The plant species coverage was estimated through the procedure proposed by MacIvor and Lundholm (2011), putting a digital pin-frame subdivided into 25 rectangular areas of $10.8 \times 10.8 \mathrm{~cm}$, each with a point $(6 \mathrm{~mm}$ diameter $)$ on the photo of each module. Percent cover (\%) was recorded as the number of points touched by any part of the plants growing in each module (leaves and dead branches were excluded) divided by 25 . The percent cover of a given species at a given date is the average of the different values recorded at this date on all the monitored modules.

\section{Irrigation and fertilization management}

The green roof is equipped with underground irrigation and sprinkling irrigation with 2 rotors (Rain Bird, 3500 series rotors, $0.12 \mathrm{~m}^{3} \mathrm{~h}^{-1}$, Azusa, California, USA). After planting in mid-June 2015 and till September 30, 2015, the green roof was irrigated with sprinkler irrigation for $12 \mathrm{~min}$, three times week ${ }^{-1}\left(6.5 \mathrm{~mm}^{\text {week }}{ }^{-1}\right)$.

All plants were fertilized with a slow-release fertilizer, Nitrophoska ${ }^{\circledR}$, on June 20, 2015, just after planting. Different amounts of fertilizer were used depending on the number of plants per module $\left(8.96 \mathrm{~g} \mathrm{~m}^{-2}\right.$ for $F$ ovina; $1.40 \mathrm{~g} \mathrm{~m}^{-2}$ for each module of A. millefolium, $A$. alpinus and $S$. minor; $1.12 \mathrm{~g} \mathrm{~m}^{-2}$ for the module of T. serpyllum and H. pilosella).

\section{Climatic and meteorological characterization}

Bologna has a warm humid temperate climate with hot and moderately dry summers; the total annual precipitation, even though quite variable, is on average $750 \mathrm{~mm}$ (Ventura et al., 2002; Matzneller et al., 2010).

During the months of the experiment (Table 2) the mean temperature was $17^{\circ} \mathrm{C}$; the minimum average monthly temperature was $4.1^{\circ} \mathrm{C}$ in January 2016 (minimum absolute temperature $-6^{\circ} \mathrm{C}$ on January 19,2016$)$, the maximum average monthly temperature was $28.8^{\circ} \mathrm{C}$ in July 2015 (maximum absolute temperature was $40^{\circ} \mathrm{C}$ on July 22 and 23,2015 ). The total precipitation was $619.4 \mathrm{~mm}$; the driest month was July 2015 (0.8 $\mathrm{mm}$ ), whereas October 2015 and February 2016 were the months with the highest precipitation (113.4 and $147.6 \mathrm{~mm}$, respectively). 
Table 2. Average monthly temperature (T) and total monthly precipitation (P) during the period of the experiment (June 2015-May 2016). Data were collected at the agrometeorological station at the University of Bologna experimental farm of

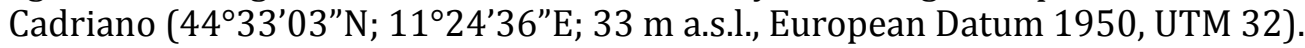

\begin{tabular}{lcccccccccccc}
\hline & June & July & Aug & Sep & Oct & Nov & Dec & Jan & Feb & Mar & Apr & May \\
\hline $\mathrm{T}\left({ }^{\circ} \mathrm{C}\right)$ & 23.4 & 28.8 & 25.7 & 20.3 & 13.6 & 9.0 & 4.8 & 4.1 & 7.3 & 9.8 & 15.2 & 18.1 \\
$\mathrm{P}(\mathrm{mm})$ & 46.8 & 0.8 & 34.8 & 15.8 & 113.4 & 52.2 & 4.6 & 26.8 & 147.6 & 59.2 & 45.0 & 72.4 \\
\hline
\end{tabular}

\section{Statistical analyses}

Statistical analyses were performed by R free software. We used ANOVA test and Tukey test to identify significant differences among species, for cover or other growth parameters, considering the overall monitored period, as well as significant differences between months for cover or other growth parameters of a given species.

\section{RESULTS}

\section{General considerations}

Table 3 shows some general data on the percent cover of the six studied species over the whole period of observation. All the species increased their cover percentage. The greatest average values of cover at the end of the observation period were those of $S$. minor (73\%) and F. ovina (69\%). H. pilosella (47\%), T. serpyllum (38\%) and A. millefolium (38\%) reached moderate average cover values, whereas $A$. alpinus reached only a modest average value (19\%). F. ovina increased its percent cover by six times, passing from a starting cover of $10 \%$ to a final cover of $60 \%$. S. minor duplicated its starting cover. The other species increased their initial cover by less than two times.

Table 3. Main parameters describing the variation of percent cover values (Maclvor and Lundholm, 2011) for the six studied species over the whole monitoring period (August 2015-May 2016). All values are average values \pm standard deviation of the percent cover values recorded in each monitored module. The variation coefficient is given in brackets.

\begin{tabular}{lcccc}
\hline Species & $\begin{array}{c}\text { Percent cover } \\
\text { on August 2015 }\end{array}$ & $\begin{array}{c}\text { Percent cover } \\
\text { in May 2016 }\end{array}$ & $\begin{array}{c}\text { Maximum percent } \\
\text { cover and month }\end{array}$ & $\begin{array}{c}\text { Percent cover increase } \\
\text { (August 2015-May 2016) }\end{array}$ \\
\hline S. minor & $36 \pm 17(0.49)$ & $73 \pm 23(0.32)$ & $75 \pm 21$ (April) (0.28) & $39 \pm 16(0.41)$ \\
F. ovina & $10 \pm 6(0.55)$ & $69 \pm 22(0.32)$ & $69 \pm 22($ May) (0.32) & $59 \pm 21(0.35)$ \\
H. pilosella & $25 \pm 5(0.22)$ & $47 \pm 19(0.40)$ & $47 \pm 19($ May) $(0.40)$ & $22 \pm 17(0.77)$ \\
T. serpyllum & $36 \pm 9(0.35)$ & $38 \pm 4(0.09)$ & $47 \pm 13$ (April) (0.28) & $1 \pm 1(11)$ \\
A. millefolium & $25 \pm 17(0.68)$ & $38 \pm 22(0.58)$ & $38 \pm 22$ (May) (0.58) & $13 \pm 21(1.62)$ \\
A. alpinus & $12 \pm 4(0.30)$ & $19 \pm 6(0.33)$ & $22 \pm 12$ (April) $(0.54)$ & $7 \pm 8(1.14)$ \\
\hline
\end{tabular}

$\mathrm{s}(A$.

alpinus, S. minor, T. serpyllum) started to reduce their cover values, probably as a response to the increase in temperature and the decrease in water availability. We can note that the standard deviation and the variation coefficient values of the considered parameters are always quite high, showing a weak decreasing trend over the observation time.

\section{The species behaviour}

For each of the studied species, Figure 1 shows the variation of the average percent cover, during the period August 2015-May 2016, as well as the trends of growth of the morphological parameters monitored during the same time.

S. minor, the species with the highest final percent cover (73\% in May 2016 and 75\% in April 2016) showed a quick increase in the percent cover and in the area of the basal rosette during the first period of monitoring (August-October 2015), followed by a period of 
reduction in both parameters (October 2015-February/March 2016), which again increased in mid-spring (April) 2016. The space occupied by this species varied depending on the seasons and months of the year, but is in any case of interest since even the minimum cover is above $50 \%$.
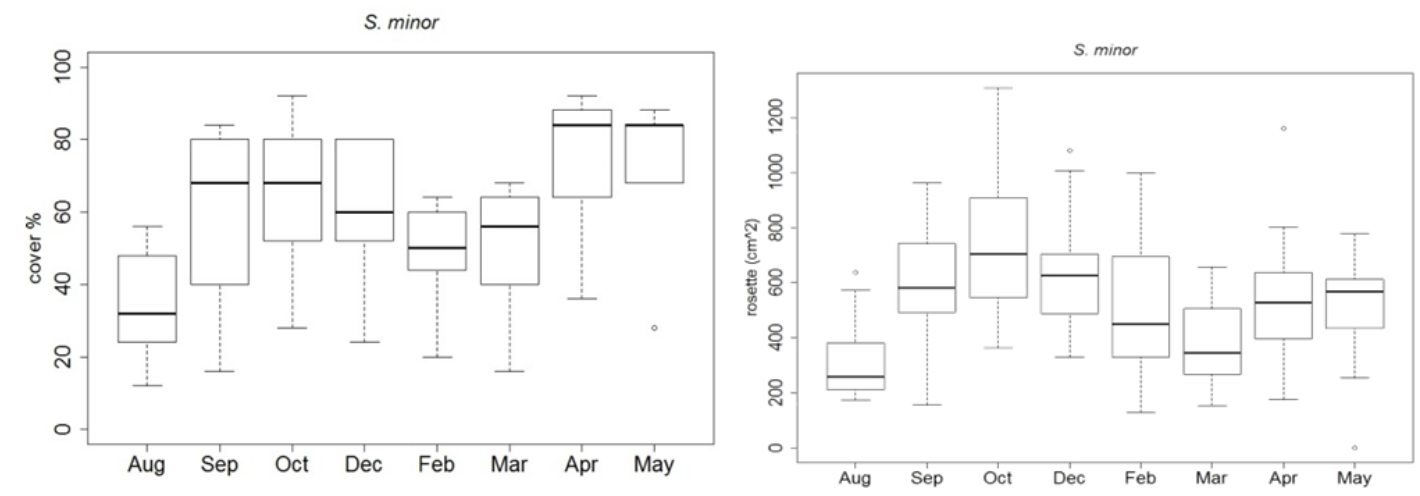

A

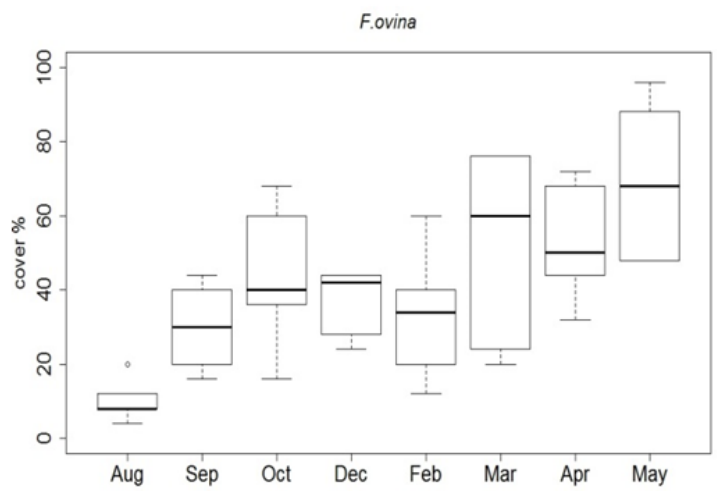

B

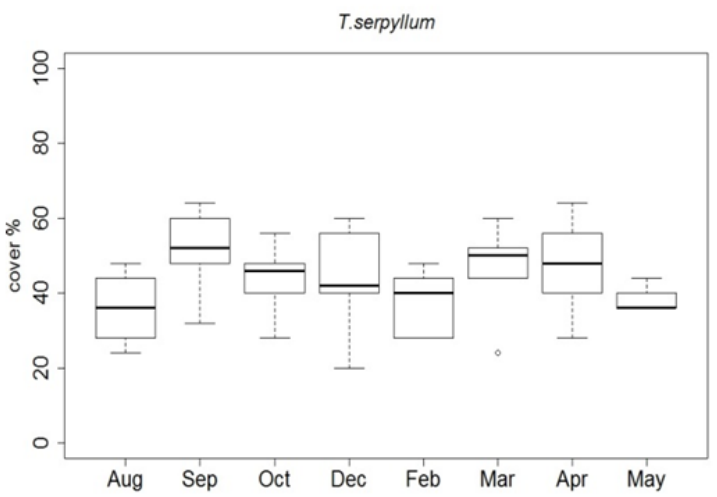

C

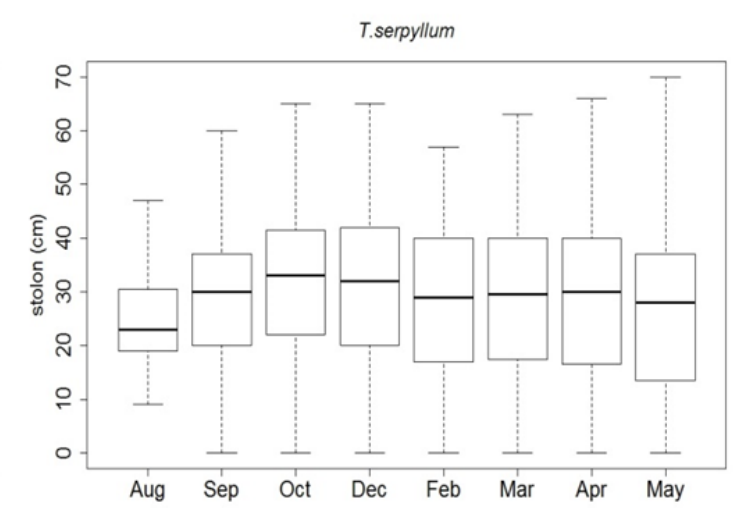

G

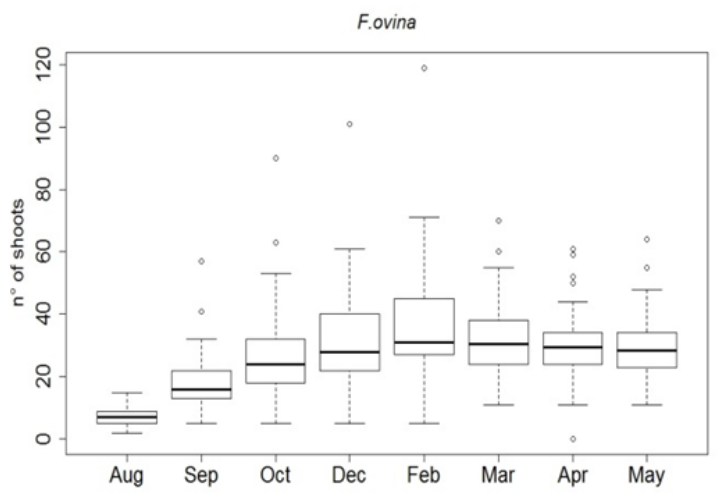

H

I

Figure 1. In the graphs are reported the averages, $1^{\text {st }}$ and $2^{\text {nd }}$ quartile, sd and outliers. In the graphs from A to F are represented the percent cover values. From the graph $G$ to the graph $\mathrm{L}$ are reported the values of different growth parameters. 

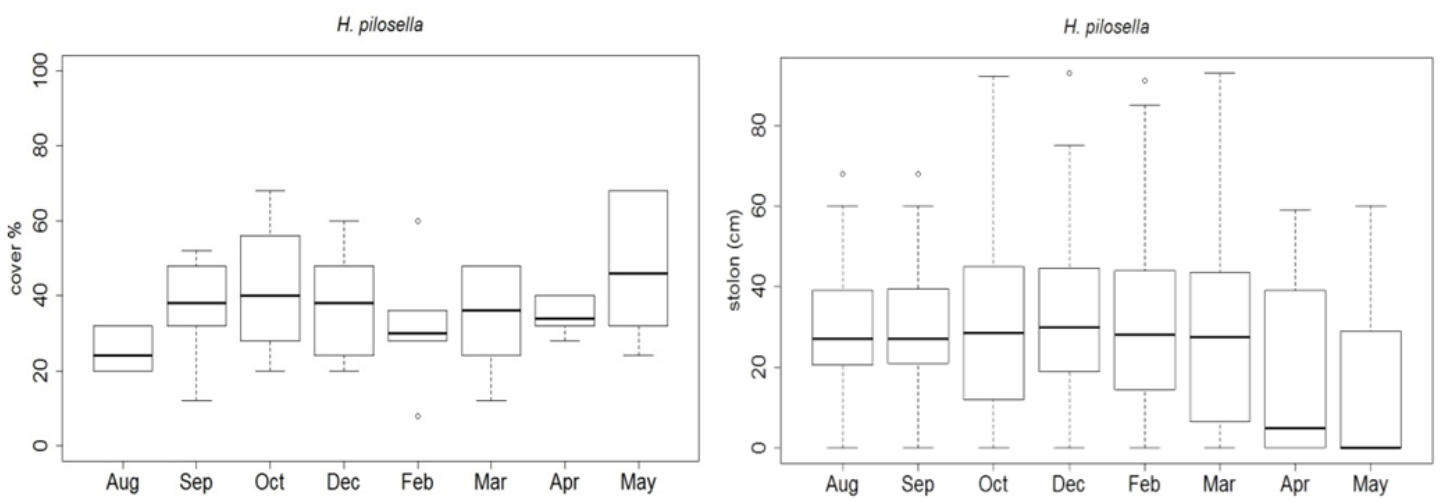

D

J
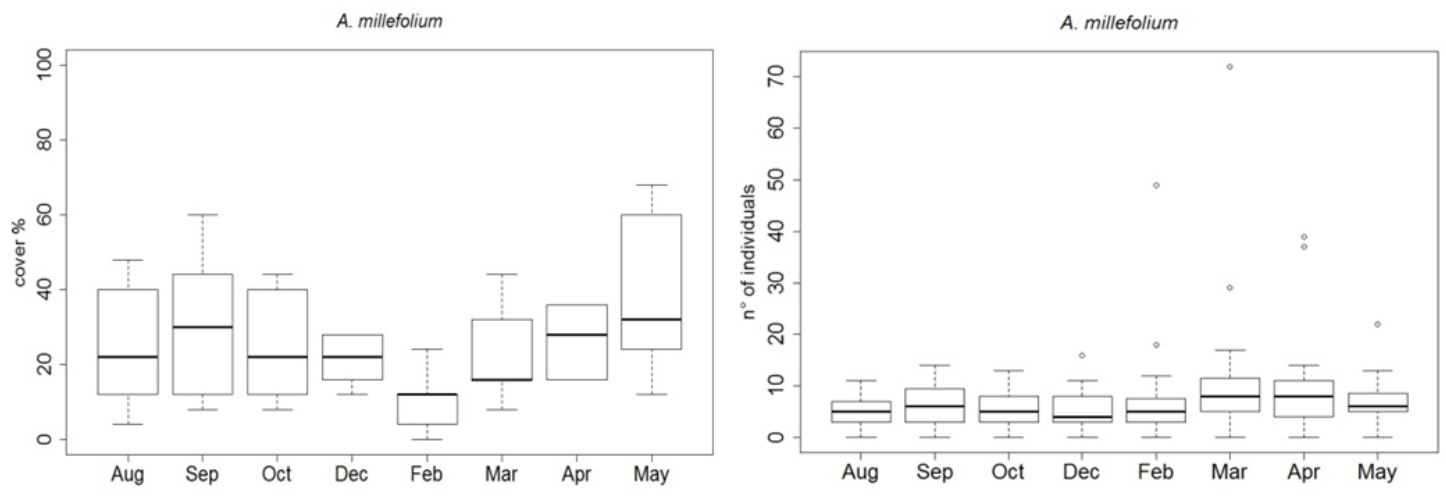

$\mathrm{E}$

K
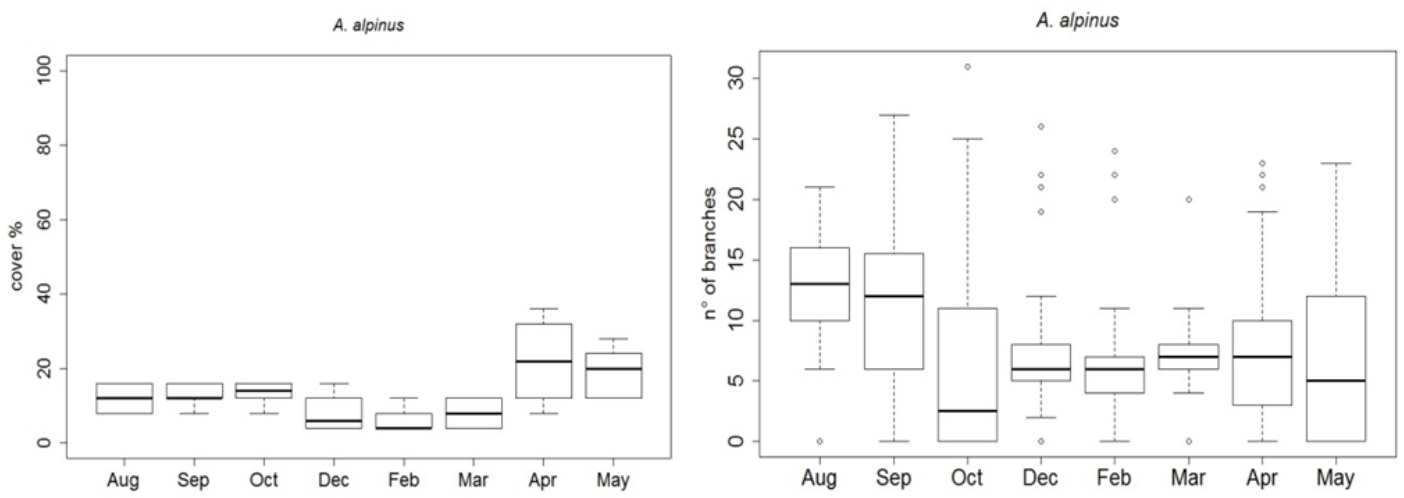

$\mathbf{F}$

L

Figure 1. Continued.

F. ovina reached a final percent cover very close to that of $S$. minor, but through a different way of growth, only moderately influenced by seasonality. Its occupation of the space increased progressively, though at different speeds, throughout the whole monitored period, except during the winter season. Its spring resprouting was precocious; the cover percentage and the number of shoots increased, respectively, from March and from February 2016.

A. alpinus showed only a limited ability to colonize the available space. The increase in percent cover during the overall monitored period is quite modest. The length of its branches strongly decreased in autumn-winter, recovering only a fraction of the initial 
length in the February-April period. The increase in percent cover in April 2016 is partly due to the production of new branches by the already existing individuals, partly to the increase in length of the monitored branches, and partly to new individuals originating from seeds of the previous year.

H. pilosella reached a moderate final percent cover characterized by slight seasonal oscillations. In contrast to the spring increase in cover, the length of the stolons showed a pronounced decrement during April and May. In fact, in this period of the year, a noticeable reorganization of the entire stolon system occurs: the old stolons die and new rosettes, producing in turn a new stolon system, are formed in May (mid spring) at the rooting points of the old stolons.

T. serpyllum has a growth pattern similar to that of $H$. pilosella. The elongation of the monitored stolons, after an initial noticeable growth, stopped and new stolons were formed (March and April) at the rooting points of the old stolons. With respect to $\mathrm{H}$. pilosella, the disappearance of the old stolons is less evident and new biomass is produced earlier, at the start of spring, when temperatures are not so high.

A. millefolium shows a very dynamic pattern of space occupation, with an evident stationary period in winter. Vegetative propagation and sexual reproduction interacted reciprocally, concurring in the noticeable increment of percent cover from February to May 2016. The production of new shoots through vegetative propagation occurred very early, in February and March 2016, quickly recovering the number of units bearing reproductive structures (capitula). From March to May the percent cover increased mainly through the production of new individuals by sexual reproduction. Over one year, the production of new individuals balanced the death of the old ones.

Average cover values, however (Figure 2a), do not give enough information on the species with the best cover capacity overall the year. Average growth rate (Figure 2b), instead, can give more complete information on this important and interesting characteristic. F. ovina showed positive increment of coverage during the entire monitoring period. In the winter, the growth slows down, but the cover does not decrease significantly as for other studied species. This is an important aspect to consider, because during a period with a reduced plant coverage, many green roof properties could be reduced.
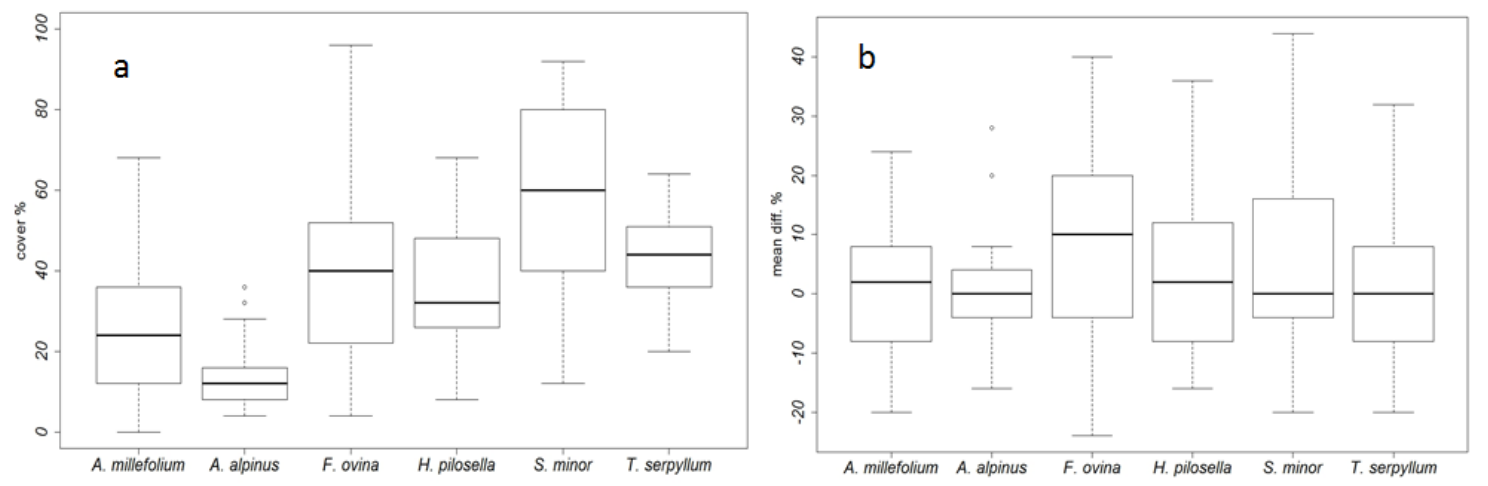

Figure 2. Average percent cover value of each species (a) and average growth rate (b) over the whole monitoring period (August 2015-May 2016).

\section{DISCUSSION}

Even if the six studied species are very common and well-known species of the Italian and European flora, the monitoring of their development over ten consecutive months allowed us to better understand their behaviour in the colonization of space, the period of maximum/minimum cover, their persistence throughout the seasons and, on the whole, their pattern of growth, in particular on an extensive green roof, under the stratification, kind of substrate and management here described and adopted.

Among the species that produce a continuous cover, F. ovina is of particular interest 
because of its compact and dense tufts, persisting throughout the year. In spring and in autumn, as for all the microtherm grasses, when the mean monthly temperature ranges between $15-25^{\circ} \mathrm{C}, \mathrm{F}$ ovina shows an active vegetative propagation (Verzotto, 2013), leading to a quick increment of shoots and of the size of the tufts, but even in winter the number of shoots do not decrease and the size of the tufts do not change significantly. Even if the species is highly tolerant to drought and to low fertility levels (Grime et al., 1988; Casler, 2006), a moderate fertilization and irrigation, as in the first period of our experiment, seems to improve its performances (Catalano et al., 2016).

The behaviour of $S$. minor, on the other hand, is quite different and of lesser interest due to the very pronounced seasonality of its cover. Both in our experience, and in that of other authors (Sydes and Grime, 1984; Grime et al., 1988), the rosettes of S. minor increased their size in spring and in autumn, reaching high percent cover values, but notably decreased in winter and, probably, also in summer (not reported here) because of the drought conditions typical of this period.

Finally, among the species with a compact structure, A. alpinus showed a much more marked seasonality, as well as a particular behaviour: the cover of the old individuals increased temporarily during a very limited spring period (Pignatti, 1982) and contributed little to the increment of the space occupied on the green roof modules. The effort for space occupation by this species mainly focuses on sexual reproduction (Bonnier, 1927; Brown, 1995) with an abundant seed production that will germinate during the next good season.

Another type of growth pattern, more dynamic, involving a periodical or continuous reorganization of the spatial distribution of the vegetative or of the reproductive structures characterizes the species that colonize the available space, forming a discontinuous cover with many empty patches. In terms of increase in cover percentage, the results are quite different for each species, but are in any case lower than those of $F$. ovina and $S$. minor. Species such as H. pilosella and T. serpyllum are subjected to a periodic re-arrangement of the positions where the new individuals, originated through vegetative propagation, developed and take nutrients. The contribution of sexual reproduction for the colonization of available space is not so significant, as the moderate increase in cover percentage of $H$. pilosella is due to the intense production of new stolons. Species such as A. millefolium instead, showed an important rearrangement in the spatial distribution of the new individuals originating from seeds and a modest modification of the percent cover of the vegetative propagation structures.

However, particular abilities in drought tolerance and/or in the use of water can significantly modify this general behaviour. T. serpyllum, for example, because of its creeping chamaephyte suffruticose habitus, can reduce transpiration (Schulz et al., 2005; Caneva et al., 2015) and more easily tolerate drought. Its use has thus been experimented on green roofs in many Mediterranean areas (Provenzano et al., 2010; Vestrella et al., 2015). At the same time, as indicated by our data during the first period of monitoring, T. serpyllum can develop more quickly than F. ovina, if irrigated, and can sometimes become dominant (Vestrella et al., 2015).

These two different patterns of growth determine a different presence and coverage of the studied species over the year and, consequently, a different aptitude for their utilization in green roofs. It would be interesting to study how the compact species type could interact and persist when in competition with the spreading species type, on a green roof where they are contemporarily present. We hypothesize a decreasing ability of persistence, from $F$. ovina, S. minor, A. millefolium, $H$. pilosella, T. serpyllum to A. alpinus. Our findings are consistent with the observations of Pakeman et al. (2002) on natural grasslands, over a much longer period of years, where H. pilosella and T. praecox proved to be poorly persistent species in comparison with $S$. minor and A. millefolium.

\section{CONCLUSIONS}

The perennial species of the arid and semi-arid herbaceous plant communities represent a potentially interesting pool of species to use in the realization of plant covers for urban green roofs, as a valid alternative to the Sedum species. All the species under study 
survived and reproduced vegetatively and sexually during the experiment, so our study will hopefully increase the interest in the use of wild plant species on green roofs. However, the results obtained underlined the importance of a more precise knowledge of the behaviour of a group of different species, in order to select those more apt to carry out specific functions and ecosystem services.

Under the adopted management of irrigation and fertilization, only two of the tested species produced a good ground cover, and of these, only F ovina can assure a wellestablished cover throughout the year. In order to design green roofs with an appreciable specific biodiversity (Rosenzweig, 2016), species other than the dominant one should be taken into consideration, even if their cover capacity is less performing. A wide mixture of wild species on a green roof will increase the urban biodiversity and, consequently, improve the eco-system service potential (Cook-Patton and Bauerle, 2012; Blanusa et al., 2013). Among the tested species $A$. millefolium demonstrated a good colonization capacity through the abundant production of seeds and their efficient dispersal. By an appropriate calibration of irrigation and fertilization, better results could be obtained even from less performing species. We hypothesize that $H$. pilosella and T. serpyllum, for example, but in general all the species here considered, could positively respond to a little more availability of water and nutrients.

The proposal to use perennial species of arid and semi-arid herbaceous plant communities for green roofs and other urban green infrastructures can thus be positively evaluated, but will need further experiments in order to obtain the best possible results. Such experiments should define the most parsimonious water and nutrient management able to induce a satisfactory biomass production through minimal external inputs, thus exploiting the adaptations of these species to poor and limiting habitats (Heil and Diemont, 1983; Catalano et al., 2016).

\section{Literature cited}

Aronson, M.F., La Sorte, F.A., Nilon, C.H., Katti, M., Goddard, M.A., Lepczyk, C.A., Warren, P.S., Williams, N.S., Cilliers, S., Clarkson, B., et al. (2014). A global analysis of the impacts of urbanization on bird and plant diversity reveals key anthropogenic drivers. Proc. Biol. Sci. 281 (1780), 20133330 https://doi.org/10.1098/rspb.2013.3330. PubMed

Blanusa, T., Vaz Monteiro, M.M., Fantozzi, F., Vysini, E., Li, Y., and Cameron, R.W.F. (2013). Alternatives to Sedum on green roofs: can broad leaf perennial plants offer better "cooling service"? Build. Environ. 59, 99-106 https://doi.org/10.1016/j.buildenv.2012.08.011.

Bonnier, G. (1927). Flore Complète Illustrée en Couleurs de France, Suisse et Belgique (Paris: E. Orlhac; Neuchâtel: Delachaux et Niestlé; Bruxelles: J. Lebègue \& Cie), pp.120.

Brown, D. (1995). Encyclopedia of Herbs \& Their Uses (London, UK: Dorling Kindersley), pp.424.

Brenneisen, S. (2006). Space for urban wildlife: designing green roofs as habitats in Switzerland. Urban Habitats $4(1), 27-36$.

Caneva, G., Kumbaric, A., Savo, V., and Casalini, R. (2015). Ecological approach in selecting extensive green roof plants: a data-set of Mediterranean plants. Plant Biosyst. 149 (2), 374-383 https://doi.org/10.1080/11263504. 2013.819819.

Casler, M.D. (2006). Perennial grasses for turf, sport and amenity uses: evolution of form, function and fitness for human benefit. J. Agric. Sci. 144 (3), 189 https://doi.org/10.1017/S0021859606006137.

Catalano, C., Marcenò, C., Laudicina, V.A., and Guarino, R. (2016). Thirty years unmanaged green roofs: ecological research and design implications. Landsc. Urban Plan. 149, 11-19 https://doi.org/10.1016/j.landurbplan.2016. 01.003.

COM. (2013). Communication from the Commission to the European Parliament, the Council, the European Economic and Social Committee and the Committee of the Regions. http://ww.w.xploit-eu.com/pdfs/ Europe\%202020\%20Flagship\%20Initiative\%20INNOVATION.pdf.

Cook-Patton, S.C., and Bauerle, T.L. (2012). Potential benefits of plant diversity on vegetated roofs: a literature review. J. Environ. Manage. 106, 85-92 https://doi.org/10.1016/j.jenvman.2012.04.003. PubMed

Del Barrio, E.P. (1998). Analysis of the green roofs cooling potential in buildings. Energy Build. 27 (2), 179-193 https://doi.org/10.1016/S0378-7788(97)00029-7. 
Dunnett, N., and Kingsbury, N. (2004). Planting options for extensive and semi-extensive green roofs. Paper presented at: The Second Annual Greening Rooftops for Sustainable Communities Conference (Portland, OR, USA).

Franzaring, J., Steffan, L., Ansel, W., Walker, R., and Fangmeier, A. (2016). Water retention, wash-out, substrate and surface temperatures of extensive green roof mesocosms - results from a two year study in SW-Germany. Ecol. Eng. 94, 503-515 https://doi.org/10.1016/j.ecoleng.2016.06.021.

Frazer, L. (2005). Paving paradise: the peril of impervious surfaces. Environ. Health Perspect. 113 (7), A456A462 https://doi.org/10.1289/ehp.113-a456. PubMed

Grime, J.P., Hodgson, J.G., and Hunt, R. (1988). Comparative Plant Ecology: a Functional Approach to Common British Species (London, UK: Unwyn Hyman), pp.742 https://doi.org/10.1016/0169-5347(89)90130-4.

Heil, G.W., and Diemont, W.H. (1983). Raised nutrient levels change heathland into grassland. Vegetatio 53 (2), 113-120 https://doi.org/10.1007/BF00043031.

Köhler, M. (2003). Plant survival research and biodiversity: lessons from Europe. Paper presented at: First Annual Greening Rooftops for Sustainable Communities Conference, Awards and Trade Show (Chicago, USA).

Lundholm, J.T. (2006). Green roofs and façades: a habitat template approach. Urban Habitats 4, 87-101.

MacIvor, J.S., and Lundholm, J.T. (2011). Performance evaluation of native plants suited to extensive green roof conditions in a maritime climate. Ecol. Eng. 37 (3), 407-417 https://doi.org/10.1016/j.ecoleng.2010.10.004.

Matzneller, P., Ventura, F., Gaspari, N., and Rossi Pisa, P. (2010). Analysis of climatic trends in data from the agrometeorological station of Bologna-Cadriano, Italy (1952-2007). Clim. Change 100 (3-4), 717-731 https://doi. org/10.1007/s10584-009-9686-z.

Monterusso, M.A., Bradley Rowe, D., and Rugh, C.L. (2005). Establishment and persistence of Sedum spp. and native taxa for green roof applications. HortScience 40 (2), 391-396.

Oberndorfer, E., Lundholm, J., Bass, B., Coffman, R.R., Doshi, H., Dunnett, N., Gaffin, S., Köhler, M., Liu, K.K.Y., and Rowe, B. (2007). Green Roofs as urban ecosystems: ecological structures, functions, and services. Bioscience 57 (10), 823-833 https://doi.org/10.1641/B571005.

Pakeman, R.J., Pywell, R.F., and Wells, T.C.E. (2002). Species spread and persistence: implications for experimental design and habitat re-creation. Appl. Veg. Sci. 5 (1), 75-86 https://doi.org/10.1658/1402-2001(2002)005[0075: SSAPIF]2.0.CO;2.

Pignatti, S. (1982). Flora d'Italia (Bologna, Italia: Edagricole), pp.625.

Porsche, U., and Köhler, M. (2003). Life cycle costs of green roofs: a comparison of Germany, USA, and Brazil. Paper presented at: RIO 3 - World Climate and Energy Event (Rio de Janeiro, Brazil).

Provenzano, M.E., Cardarelli, M., Crasso, M., and Colla, G. (2010). Evaluation of potential green roof plant species in a Mediterranean climate. Paper presented at: World Green Roof Congress - Green Roof for a Changing Climate (London, UK).

Rosenzweig, M.L. (2016). Green roofs: new ecosystems to defend species diversity. Isr. J. Ecol. Evol. 62 (1-2), 7-14 https://doi.org/10.1080/15659801.2015.1121600.

Schulz, H., Özkan, G., Baranska, M., Krüger, H., and Özcan, M. (2005). Characterisation of essential oil plants from Turkey by IR and Raman spectroscopy. Vib. Spectrosc. 39 (2), 249-256 https://doi.org/10.1016/j.vibspec.2005. 04.009.

Sydes, C.L., and Grime, J.P. (1984). A comparative study of root development using a simulated rock crevice. J. Ecol. 72 (3), 937-946 https://doi.org/10.2307/2259542.

Ventura, F., Rossi Pisa, P., and Ardizzoni, E. (2002). Temperature and precipitation trends in Bologna (Italy) from 1952 to 1999. Atmos. Res. 61 (3), 203-214 https://doi.org/10.1016/S0169-8095(01)00135-1.

Verzotto, A. (2013). Impiego di specie macroterme per la formazione di tappeti erbosi in zone di transizione: aspetti gestionali. Bachelor thesis, Degree in Landscape, Parks and Gardens (University of Padova).

Vestrella, A., Savé, R., and Biel, C. (2015). Performance of two simulated green roofs in the Mediterranean area. J. Agric. Sci. 7 (11), 59-75 https://doi.org/10.5539/jas.v7n11p59.

Warwick, S.I., and Black, L. (1982). The biology of Canadian weeds 52. Achillea millefolium L. S.L. Can. J. Plant Sci. 62 (1), 163-182 https://doi.org/10.4141/cjps82-024.

White, W., and Snodgrass, E. (2003). Extensive green roof plant selection and characteristics. Paper presented at: 1st North American Green Roof Conference: Greening Rooftops for Sustainable Communities (Chicago, IL, USA). 